\title{
The spatial value of local houses around Islamic Boarding School in Mlangi Moslem settlements, Yogyakarta, Indonesia
}

\author{
Nensi Golda Yuli* \\ Department of Architecture, Universitas Islam Indonesia, Yogyakarta, Indonesia
}

\begin{abstract}
Many houses around Mlangi Muslim settlement refer to the historical aspect of settlement in its spatial layout as the Moslem settlements. Mlangi well known as Kampung Santri - village with many of Islamic Boarding Schools (Pondok Pesantren in Indonesia term) where students live in there- since 1920an. This paper will describe how the spatial value of local houses around Islamic Boarding Schools in Mlangi Moslem settlements. The naturalistic-phenomenology method was the research method for data collection. Data got from subsequent interview after the appearance theme from one research object to the next. Any argument that correlated with the spatial value grouped as the same theme and analyzed as the substantive concept about the spatial value in the houses. The room layout from each home drawn one by one as the existing condition and the value of the room got from the comments of the owner. Cross-checking information technic from the members in the house helped the research to mention many spatial values in-house and then conclude as the room concept and its correlation to the stigma as the Kampung Santri and Moslem Settlements. It also compares the similarity of the indoor room layout and zone in Pondok Pesantren. From existing condition and interviews found that all the houses have the similar function and room layout with the Pondok Pesantren around it. 6 observed houses and 15 interviewed owners stated that they want to make their house as the places and spaces for teaching holy Al Qur'an same like in Pondok Pesantren. That is like a dream come true if a house can hold any recitation and teach holy Al Qur'an and Islamic Knowledge to the neighbor. From this condition, researchers conclude that there is close relation about the significance building in one settlement to their neighbor building, not only in the activity in each house but also in room layout and zone. Religious value and people understanding and dream about the ideal space even get impact from it.
\end{abstract}

\section{Introduction}

The spatial value transforms from the spatial meaning while a home entails a physical space that influences the emotional and mental needs of individuals [12] and is organized according to a particular order of social principles [9]. Thus, spatial relation must be

*Corresponding author: nensi@uii.ac.id 
considered in the design of living spaces, especially in houses where individuals perform many of their daily activities [2].

The spatial value in Moslem settlements can draw how the people concept about their house related to the arrangements which stamped as Moslem settlements. As one of the oldest Moslem settlements in Yogyakarta, Mlangi village contributed in the spread of Islam in the west site of Yogyakarta Special Region. Nowadays, many pesantrens (Islamic Boarding School) build around its grand mosque, Pathok Negoro Mlangi Mosque. It was the first idea from $1^{\text {st }}$ King of Yogyakarta to make the settlement at west site Yogyakarta as the center of Islam spread in Yogyakarta. As the old city planning, another place of Yogyakarta, in north, east and south also built A Pathok Negoro Mosque to develop Islam from the corners of the city. Recently, only in Mlangi village the indigenous atmosphere of Moslem settlements still sustain which didn't have any significant changes from its first existence.

The research was conduct to explore how the houses in the village have similarity in room layout with exist Pesantren int there. Room layout indicated spatial value from house owner and its family who dedicated their house for the same activities like in Pesantren. An only rich person or people has a broad relation and networking to other pesantren outside village has the ability to build pesantren in there. The other has same dream and vision about their houses, but the economic condition makes they only try to set the house like pesantren. This condition explored by this research to seek how far the houses implemented the owner value about spatial related to pesantren around it.

\section{Method}

The naturalistic-phenomenology method used as data gathering technics. Six houses which explored by interview to the occupants observed by phenomenology features in the site. The information from users that stated the room function in their houses plotted in floorplan drawing. The room layout plot based on the statement of the user, not the researcher interpretation. Floorplan picture interpretation and crosschecking to the occupants for the spatial value behind that compared to the general room layout in Mlangi pesantren. It draws how the people's houses around pesantren in spatial value. The location of the observed house in this research as in figure 1:

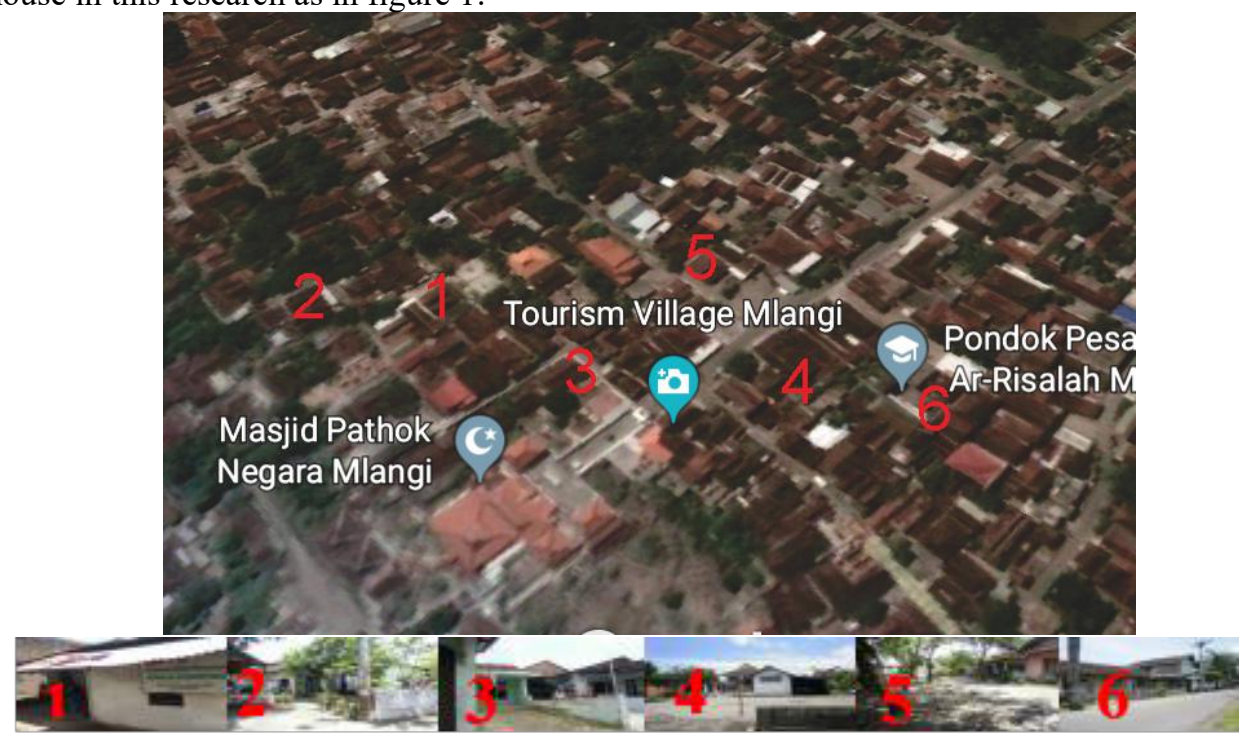

Fig. 1. The location of observed houses. 


\section{Theoretical review}

The spatial value has the close relationship to the spatial quality that identified as view, privacy, lighting, spatiality, spatial arrangements, the transition between public and private spaces, and perceived, built, and human densities [1]. In its conceptual meaning, a house bears such notions as tranquility, peace of mind, spiritual and metal as well as local safety that full fill these needs [7]. From sociology and psychology literature, values are typically conceptualized as fundamental ideas and enduring principles that inform peoples' judgments [3];[10]; [13]. The value could be understood as the value of people; assigned values is how places, species and ecosystems are valued by people [5]. Assigned values may be related to the underlying environmental concerns and worldviews that people hold [11]; [15]. Assigned values could be a better predictor of spatial behavior than held values, together with beliefs and norms, influence assigned value, and therefore are only indirectly linked to environmental behavior [14]. Relational values reflect that people could have strong bonds to places that influence their preferences for uses in a location as well as their attitudes towards management actions [4].

The most critical challenge in eown territory is the incompatibility of the physical and space of the residential complex with the cultural and behavioral properties of the residents [8]. Social relation between people in a time and place is spread dialectic semantic of culture that is explained in a relationship with the human environment and place [6].

The concept and function of space created have close ties to understand the way of life of the community. Lifestyle factors influence the shape and arrangement of area in the house [16].

\section{Research findings}

From existing condition, six houses observed by its layout, function of the room and spatial value from occupants in-depth interview using phenomenology method. The research findings is in table 1:

Table 1. Summary of The Houses Exploration in Research Area.

\begin{tabular}{|c|c|c|c|}
\hline $\begin{array}{l}\text { Number of } \\
\text { Explored } \\
\text { House }\end{array}$ & Floor Plan & $\begin{array}{c}\text { Dominant Function } \\
\text { Area }\end{array}$ & $\begin{array}{c}\text { Hidden reason from } \\
\text { occupant about the large } \\
\text { zone allocation for living } \\
\text { room } \\
\end{array}$ \\
\hline House 1 & 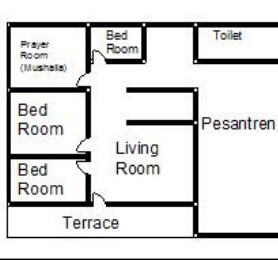 & $\begin{array}{l}\text { The Living room use } \\
\text { for Al Qur'an } \\
\text { Recitation and } \\
\text { There are Pesantren as } \\
\text { Educational Facilites } \\
\text { for communities in the } \\
\text { House }\end{array}$ & $\begin{array}{l}\text { Most of the house zone } \\
\text { dedicated for Pesantren } \\
\text { activities, like the occupant } \\
\text { vision to build pesantren } \\
\text { after his convection } \\
\text { business bankrupted }\end{array}$ \\
\hline House 2 & 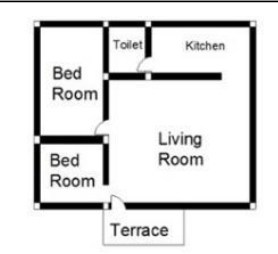 & $\begin{array}{l}\text { Living Room for } \\
\text { Multiactivities i.e: } \\
\text { Recitation for } \\
\text { Neighbour and } \\
\text { minibusiness place } \\
\text { activities }\end{array}$ & $\begin{array}{l}\text { All activities in the house } \\
\text { only for business and } \\
\text { recitation, although the } \\
\text { users only teach kids } \\
\text { around the house in the } \\
\text { evening for holy qur'an } \\
\text { recitation }\end{array}$ \\
\hline
\end{tabular}




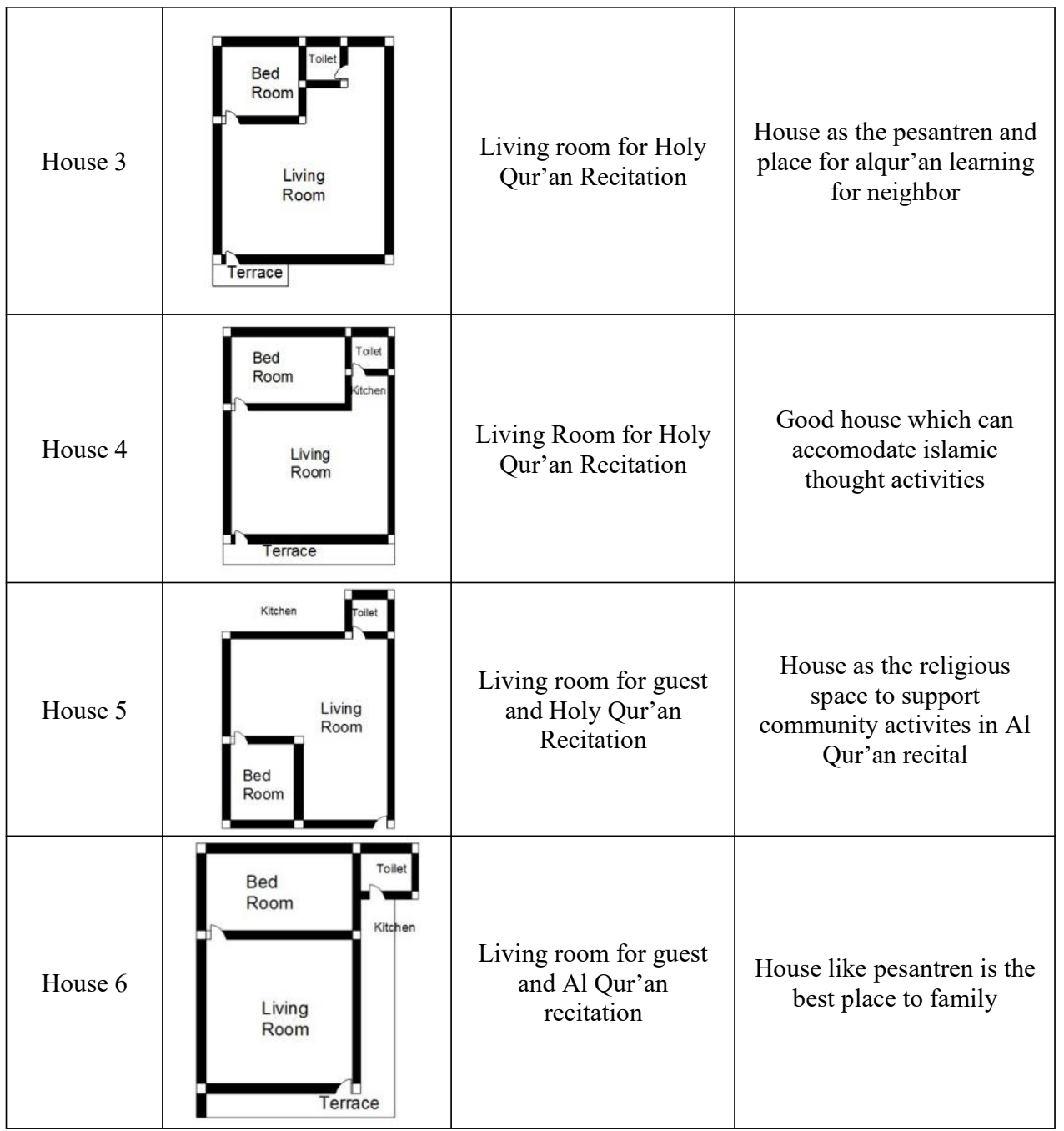

House 1 is a house with pesantren (Islamic boarding school) in it. Students of pesantren live in there. There are three families in that house, the house owner, the pesantren owner (first son of house owner) and the youngest daughter of the family. They live together with their role for the community. The house owner hs significant role for cities, as the head of Mosque organizer (Takmir Masjid). The son is the head of Pesantren (Kyai), and the daughter has the small shop near the main road that sell Moslem wear. In the house, they also have mushalla, little place to pray together. All the room in the houses dedicated for religious activities, such as received the guest from other pesantren, hold the Al Qur'an recitation, religious meeting with neighborhood and also to entertain business relation for the daughter. All the activity, from entertaining guests, meeting with a neighbor, hold the recitation including teaching small group for Islamic teaching do in the living room. Their understanding for space in the house is a space for multifunction activities to support pesantren activities from teaching and learning, Al Qur'an recitation and give the services for guest who want to know so far about Islamic knowledge.

For house 2, the main activity is convection business. House separates into the living room, bedroom, kitchen, and toilet. The house owner also holds recitation in the evening for around children. They have a dream to be their house as the Islamic teaching place. In 
their mind, a good home is a house who has dominant religious activity in spatial layout owner set living room for multifunctional room, both for business and recitation. But in the same time, the recitation or other religious activities have higher priority than business activity.

In-house 3,4,5 and 6, all types are similar in spatial layout. Majority of spaces is for the living room, only small space for bedroom and service (toilet). These houses often use for communities meeting exclude pesantren activities. The people around Mlangi settlements have two different activities, pesantren activities, and non pesantren activities. Both support each other. The spatial use for both activities also help each other. But in some activities, there are recitation group for non-pesantren, where held in people houses at a regular schedule, from one house to another house. So, the people's house in Mlangi Muslim Settlements should accommodate regular activities by large living room in that house or they should provide a place in front of their house using tend to held regular recitation and meeting. These types similar to pesantren's indoor layout like in figure 2 . In figure 2 , all the room dedicated to eduational activities i.e teaching Islamic knowledge, reciting Holy $\mathrm{Al}$ Qur'an and also study about the history of muslim world.

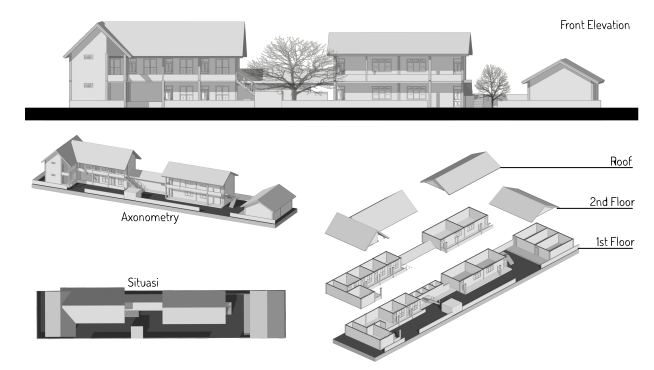

Fig. 2. One Pesantren Type in Mlangi.

\section{Discussion}

In Mlangi village, almost activities using the living room area. From business, entertaining guests, Al Qur'an recitation and small teaching about Islamic knowledge occur in the living room. Different from research in 2015 by Wahab in Melaka residents found that in Malay house, people using veranda area for reciting Al Qur'an as a public area. From this research, we know there is open space in the house to accommodate religious activity like in Mlangi. Also in Malay, private user Al Qur'an recitation held in private room in the main house. This area is the center and isolated area and can only access by permission. It is just for family. Beside the public space in house scale, a house in Malay divide the house for different user in use. But in Mlangi, people feel they are coming from one big family in the settlement, so there are no private or public for space allocation. In history, Mlangi ancestor is the person who develops the settlement to be a Moslem settlement, Kyai Nur Iman, a family member of Yogyakarta Sultanate. And all the houses around the mosque had close relation to each other and claimed as the blue blood generation from Yogyakarta Sultanate.

If we compare to the research in Iranian house by Alitajer 2016 indicated that privacy is not respected in modern houses than traditional houses. Alitajer stated today the privacy in the house as the rare thing to develop. Both current and classic house, connectivity and integration between room are minimal. From this research findings also confirmed that in some country spatial value which can indicated from the privacy, actually not find both in traditional and modern houses. The houses need private space for the occupants but if the owner live around the his/her central family, like in Mlangi, there are no privacy in the 
house. All room in house is the public place for anyone who come. There is some space that could be intervention by non family member. Most of traditional house in Malay use serambi or veranda as a space to held prayer activities [17].

\section{Conclusion}

From six houses, all users commented that the house related to pesantren in room layout. Their spatial values implemented how they set room allocation. The manifestation of the value entirely draws for living room allocation portion in the house. Spatial value also brings in their mind

From this condition, research conclude that there is close relation about the significance building in one settlements to their neighbor building, not only in the activity in each house but also in room lay out and zone. Religious value and people understanding and dream about the ideal space even get impact from it.

\section{Acknowledgement}

The Fundamental Research ostensibly supports this research for Excellency University Grant from Ministry of Research, Technology and Higher Education of The Republic of Indonesia (PDUPT RISTEK DIKTI) 2019 entitled The Moderation of Pondok Pesantren Building Design Standard based on Vernacularity and the Development of Its Activities for Intelligent, Sustainable and Disaster Responsive Masterplan in Mlangi Village, Nogotirto, Sleman, Yogyakarta.

\section{References}

1. Acre, F., Wyckmans, A. 2014, Spatial quality determinants for building renovation: a methodological approach to the development of spatial quality assessment. J. $\begin{array}{llll}\text { Sustainable } & \text { Technol. Urban Dev. }\end{array}$ http://dx.doi.org/10/1080/2093761X.2014.923793

2. Alitajer, Saeid and Ghazaleh Molavi Nojoumi. 2016. Privacy at home: Analysis of behavioral patterns in the spatial configuration of traditional and modern houses in the city of Hamedan based on the notion of space syntax. Frontiers of Architectural Research (2016) 5, 341-352

3. Brown, T. C. (1984). The concept of value in resource allocation. Land Economics, 60(3), 231-246. https://doi.org/10.2307/3146184.

4. Chan, K. M. A., Balvanera, P., Benessaiah, K., Chapman, M., D.az, S., G.mezBaggethun, E., et al. (2016). Opinion: Why protect nature? Rethinking values and the environment. Proceedings of the National Academy of Sciences, 113(6), 1462-1465. https:// doi.org/10.1073/pnas.1525002113.

5. Ives, C. D., \& Kendal, D. (2014). The role of social values in the management of ecological systems. Journal of Environmental Management, 144, 67-72. https://doi.org/10.1016/j.jenvman.2014.05.013.

6. Jencks, Charles (1996), What is post-modernism, Michigan, the University of Michigan Press

7. Kooshali, Atefeh Deljooy, Reza parvisi, Amir Reza Karimi Azeri, S. Bagher Hosseni. 2015. A Comparative Study on the Effect of Nature on Satisfaction with Residence at 
Detached Houses (Single Unit) and Residential Building Complex (Apartment). Social and Behavioural Sciences 201 (2015) 243-254: Elsevier 2015

8. Mashayekhi, Mohammad; Mohammadjavad Mahdavinejad, and Soghra Niroumand. 2012. Designing Family Friendly Architecture Environments. Elsevier: 2012

9. Reis, A. 2003. Original and converted social housing: spatial configuration and residents' altitude: Proceeding of the Paper presented at the $4^{\text {th }}$ International Space Syntax Symposium London.

10. Rokeach, M. (1973). The nature of human values [by] milton Rokeach. New York: Free Press.

11. Rossi, S. D., Byrne, J. A., Pickering, C. M., \& Reser, J. (2015). 'Seeing red' in national parks: How visitors' values affect perceptions and park experiences. Geoforum, 66(Suppl. C), 41-52. https://doi.org/10.1016/j.geoforum.2015.09.009.

12. Saruwono, Masran. 2012. Shouting in Silence: expression of self in private homes a dwelling, house, or home ? . Procedia - Social and Behaviour Sciences 42 (2012) 3441

13. Schwartz, S. H. (1994). Are there universal aspects in the structure and contents of human values, Journal of Social Issues, 50(4), 19-45. https://doi.org/10.1111/j.15404560. 1994.tb01196.x.

14. Seymour, E., Curtis, A., Pannell, D., Allan, C., \& Roberts, A. (2010). Understanding the role of assigned values in natural resource management. Australasian Journal of Environmental Management, 17(3), 142-153. https://doi.org/10.1080/14486563. 2010.9725261

15. Van Riper, C. J., \& Kyle, G. T. 2014. Capturing multiple values of ecosystem services shaped by environmental worldviews: A spatial analysis. Journal of Environmental Management, 145(Suppl. C), 374-384. https://doi.org/10.1016/j.jenvman.2014.06.014.

16. Wahab, Mohamad Hanif Abdul et al. 2015. Malay Furniture: Design, Function and Meaning. *, Procedding on ASEAN-Turkey ASLI (Annual Serial Landmark International) Conference on Quality of Life 2014, ABRA International Conference on Quality of Life, AQoL2014, 26-28 December 2014, Istanbul, Turkey

17. Wan Teh, W.H., Nasir, A.H., 2011. The Traditional Malay House (Fourth ed.). Penerbit Fajar Bakti, Shah Alam, Malaysia. 